\title{
PENGELOLAAN SUMBERDAYA ALAM BERBASIS MASYARAKAT DALAM UPAYA KONSERVASI DAERAH ALIRAN SUNGAI LUBUK LANGKAP DESA SUKA MAJU KECAMATAN AIR NIPIS KABUPATEN BENGKULU SELATAN
}

\author{
Deki Andes Putra ${ }^{1)}$, Satria Putra Utama ${ }^{2)}$, Rohidin Mersyah ${ }^{3)}$ \\ ${ }^{1)}$ Dinas Komunikasi dan Informatika Kabupaten Bengkulu Selatan \\ ${ }^{2)}$ Jurusan Sosial Ekonomi Fakultas Pertanian Universitas Bengkulu \\ ${ }^{3)}$ Pemerintah Provinsi Bengkulu
}

\begin{abstract}
ABSTRAK
Pengelolaan daerah aliran sungai (DAS) dilakukan untuk mengatur hubungan timbal balik antara sumber daya alam dalam DAS dan manusia agar terwujud kelestarian ekosistem serta menjamin keberlanjutan manfaat sumber daya alam tersebut bagi manusia. Artinya, setiap bentuk pemanfaatan sumber daya alam dilakukan dengan mempertimbangkan aspek-aspek kelestarian DAS. Dengan demikian manusia dapat memperoleh manfaat sumber daya alam dan jasa lingkungan secara berkelanjutan dari generasi ke generasi. Pengelolaan sumber daya alam dapat dilakukan secara partisipatif dengan melibatkan seluruh komponen masyarakat desa. Penelitian ini dilakukan di Desa Suka Maju Kecamatan Air Nipis, Kabupaten Bengkulu Selatan selama bulan Agustus 2018. Desa ini merupakan salah satu desa yang terletak di hulu DAS Lubuk Langkap. Variabel yang diamati meliputi aktivitas-aktivitas/fungsi pengelolaan sumber daya alam yang meliputi perencanaan (planning), pengorganisasian (organizing), pelaksanaan (actuating), dan pengendalian (controlling) serta peran pihak luar dalam pengelolaan sumber daya alam tersebut. Selanjutnya dilakukan analisis aspek-aspek community based dalam pengelolaan sumber daya alam, meliputi: equity (keadilan), empowerment (pemberdayaan), conflict resolution (resolusi konflik), knowledge and awarrenes (pengetahuan dan kesadaran), biodiversity protection (perlindungan keanekaragaman hayati), dan sustainable utilization (pemanfaatan berkelanjutan). Hasil penelitian menunjukkan bahwa pengelolaan sumberdaya alam sudah cukup baik dimana terlihat antusias perangkat desa dan masyarakat dalam mengembangkan daerah aliran sungai Lubuk Langkap telah berjalan, dengan adanya wisata ini menambah pendapatan masyarakat walaupun secara signifikan belum dapat dirasakan seluruh masyarakat karena baru mulai pengembangan, masyarakat mendapat pengalaman baru tentang pengetahuan dan kesadaran akan mengelolaan sumberdaya alam dan masyarakat mampu untuk melakukan perlindungan keanekaragan hayati.
\end{abstract}

Kata Kunci : daerah aliran sungai, aktivitas pengelolaan sumberdaya alam

\section{PENDAHULUAN}

Jaminan keberlanjutan DAS tersebut dapat tercapai apabila setiap aktivitas pengelolaan dijalankan berdasarkan prinsip kelestarian yang memadukan keseimbangan antara produktivitas dan konservasi untuk mencapai tujuan pengelolaan DAS sebagai berikut 1) meningkatkan stabilitas tata air, 2) meningkatkan stabilitas tanah, termasuk mengendalikan proses degradasi lahan, 3) meningkatkan pendapatan petani, dan 4) meningkatkan perilaku masyarakat ke arah kegiatan konservasi yang mengendalikan aliran permukaan dan banjir (Wulandari 2007). 
Secara garis besar, sistem DAS dapat dibagi dalam tiga bagian, yaitu bagian hulu, tengah, dan hilir. Ekosistem DAS hulu sangat penting dalam sistem DAS sebab berfungsi sebagai perlindungan sistem tata air DAS secara keseluruhan. Soemarwoto (1982) dalam Asdak (2010) menerangkan bahwa daerah hulu dicirikan sebagai ekosistem pedesaan dengan empat komponen utama, yaitu: desa, sawah/ladang, sungai, dan hutan. Dengan demikian, pengelolaan DAS hulu bukan hanya untuk menjaga fungsi tata air DAS, melainkan juga harus mampu memperbaiki mata pencaharian dan meningkatkan perekonomian masyarakat lokal secara berkelanjutan. Zoebisch et al (2005) menegaskan bahwa keseimbangan antara pemenuhan kebutuhan masyarakat lokal dan kelestarian sumber daya alam, menjadi syarat tercapainya tujuan pengelolaan DAS yang berkelanjutan.

Adapun strategi yang dipandang sebagai pendekatan yang mengedepankan partisipasi masyarakat dalam pengelolaan DAS adalah pengelolaan sumber daya alam berbasis masyarakat atau yang dikenal dengan Community Based Natural Resources Management (CBNRM). Pendekatan tersebut mulai berkembang sejak akhir 1990-an seiring bergulirnya era desentralisasi dan demokrasi.

Tujuan dari penelitian ini adalah untuk mengetahui aktivitas/fungsi pengelolaan sumber daya alam di sepanjang Aliran Lubuk Langkap dan peranan pihak luar dalam pengelolaan tersebut, untuk menganalisis aspek-aspek pengelolaan sumber daya alam berbasis. masyarakat di Aliran Sungai Lubuk Langkap.

\section{METODE PENELITIAN}

\section{Tempat dan Waktu Penelitian}

Penelitian ini dilakukan di Desa Suka Maju Kecamatan Air Nipis, Kabupaten Bengkulu Selatan pada bulan Agustus 2018.

\section{Teknik Pengumpulan Data}

\begin{abstract}
Pengumpulan data dilakukan dengan studi literatur, observasi (pengamatan) dan wawancara yang turun langsung ke lapangan.
\end{abstract}

\section{Variabel yang Diamati}

1. Sumber Daya Alam, merupakan kekayaan dan sumber-sumber alami yang dimiliki oleh Desa Suka Maju sebagai salah satu sumber penghasilan yang bisa di kelola oleh masyarakat Desa Suka Maju.

2. Pengelolaan, berkaitan dengan metode yang digunakan dalam pengelolaan sumber daya alam di desa Suka Maju oleh masyarakat.

3. Aktifitas/Fungsi Pengelolaan

a. Planning, melakukan perencanaan partisipatif dalam mengelola potensi sumber daya yang dimiliki.

b. Organizing, pengorganisasian dalam pengelolaan sumber daya alam di Desa Suka Maju dilakukan sesuai kebutuhan pada awal perencanaan dan secara fleksibel berubah sesuai perkembangan kebutuhan. Kepala desa memegang peranan penting dalam pengorganisasian tersebut.

c. Actuating, pengelolaan sumber daya alam berbasis masyarakat melalui desa dilaksanakan bersama-sama oleh semua warga Desa Suka Maju.

d. Controling, mekanisme pengendalian dalam pengelolaan sumber daya alam di Desa Suka Maju bersifat intern dan melibatkan seluruh warga secara bertahap. Pada waktu-waktu tertentu, pengurus mengadakan rapat evaluasi yang hanya melibatkan pengurus.

4. Peran Pihak Luar, yang terlibat seperti Pemerintah daerah Kabupaten Bengkulu Selatan, Lembaga Swadaya Masyarakat yang menjadi pendamping dalam pengelolaan CBNRM, serta Media Massa yang tentu akan mempublikasikan kegiatan masyarakat Desa Suka Maju.

\section{Aspek CBNRM}


a.Equity (keadilan), pengelolaan sumber daya alam berbasis masyarakat melalui desa wisata di Desa Suka Maju memberikan manfaat sosial ekonomi yang lebih adil bagi masyarakat desa.

b. Empowerment (pemberdayaan), pengelolaan sumber daya alam berbasis masyarakat di Desa Suka Maju membuat masyarakat menjadi lebih berdaya baik secara politik maupun ekonomi.

c. Conflict resolution (resolusi konflik), pengelolaan sumber daya alam dengan fokus wisata di Desa Suka Maju tak lepas dari konflik, namun dapat dikelola dengan baik

melalui skema CBNRM yang dijalankan.

d. Knowledge and awareness (pengetahuan dan kesadaran), CBNRM membuka peluang ekonomi baru yang tidak merusak lingkungan, sebaliknya mendukung pelestarian lingkungan. Kearifan lokal yang sudah ada dipadukan dengan pengetahuan ekologi dan manajemen modern untuk mengelola potensi sumber daya alam.

e. Biodiversity protection (perlindungan keanekaragaman hayati), menjadi salah satu capaian CBNRM di Desa Suka Maju. Pemanfaatan sumber daya alam untuk mendorong masyarakat untuk mengelola lingkungan dan melindungi keanekaragaman hayati beserta habitatnya. f. Sustainable utilization (pemanfaatan berkelanjutan), pemanfaatan yang terus menerus dan menjalin kerjasama dengan desa-desa sekitar sehingga akan meningkatkan penghasilan.

6. Model Konseptual CBNRM, aktifitas-aktifitas pengelolaan dilakukan secara partisipatif dengan proses yang melibatkan seluruh komponen anggota, yaitu warga desa. Komitmen yang kuat untuk menjalankan CBNRM mendorong warga desa untuk aktif berperan serta baik dengan menyumbangkan tenaga, pemikiran, maupun pendanaan pada awal program.

7. Konservasi DAS, kondisi ekologis pada bagian hulu akan membawa ekternalitas bagi daerah yang berada di hilirnya. Karena itu program konservasi kawasan DAS Lubuk Langkap memerlukan manajemen pada tingkat kawasan DAS. Sistem yang lebih besar tersusun atas sistem-sistem kecil. Sebaliknya, sistemsistem kecil tergantung pada sistem yang lebih besar untuk bertahan. Jadi tingkat yang berbeda saling membutuhkan satu sama lain.

\section{Analisis Data}

Penelitian ini menggunakan analisis data deskriptif kualitatif. Secara garis besar analisis dibagi dalam tiga kegiatan yang dilakukan secara bersamaan, yaitu reduksi data, penyajian data, dan penarikan kesimpulan (Miles \& Huberman 1992). Analisis data dilakukan secara terus-menerus mulai saat penyusunan konseptual penelitian, saat pengumpulan data di lapangan dan sesudahnya.

\section{HASIL DAN PEMBAHASAN}

\section{Gambaran Umum Lokasi Penelitian}

Desa Suka Maju merupakan salah satu dari sepuluh (10) desa di wilayah Kecamatan Air Nipis dan berbatasan langsung dengan wilayah Kecamatan Tanjung Sakti Kabupaten Lahat Provinsi Sumatera Selatan yang teletak lebih kurang $3 \mathrm{Km}$ kearah utara dari pusat Kecamatan Air Nipis. Kondisi topografi wilayah DAS Lubuk Langkap beragam mulai dari datar, berombak, bergelombang, berbukit hingga bergunung. Dengan kondisi topografi seperti itu, penggunaan lahan pun cukup beragam, yaitu berupa kawasan hutan, tegalan, kebun campur, perkebunan, permukiman, sawah, rawa, dan kebun rakyat.

Desa Suka Maju mempunyai luas wilayah \pm 2.500 ha yang sebagian besar digunakan untuk pertanian dan perkebunan sedangkan selebihnya digunakan untuk lahan pemukiman, TPU, perkantoran dan lain sebagainya. Desa ini sama dengan kebanyakan desa yang ada diwilayah Indonesia mempunyai iklim musim 
kemarau dan penghujan, hal ini tentu berpengaruh langsung dengan pola tanam pada lahan pertanian yang ada di Desa Suka Maju Kecamatan Air Nipis.

\section{Keadaan Kehidupan Masyarakat Suka Maju}

Masyarakat Suka Maju adalah masyarakat yang majemuk, yang mempunyai kultur yang berbeda, mata pencaharian masyarakat pun berbeda, ada yang pegawai negeri, ada yang petani, ada yang buruh tani, ada pula yang pedagang, tetapi kebanyakan masyarakat adalah petani dan buruh tani. Sebagai masyarakat yang kebanyakan petani, Desa Suka Maju mempunyai lahan yang luas untuk pertanian akan tetapi kurangnya sumberdaya manusia yang memadai mengakibatkan banyak lahan yang belum dikelola dengan baik, bahkan ada juga lahan yang belum terkelola dengan baik, serta lahan sawah yang dialihkan fungsikan. Diharapkan ke depan petani di Desa Suka Maju ini dapat mencapapi hasil maksimal dengan adanya perhatian pemerintah.

Desa dengan sumber daya alam yang melimpah tersebut didiami oleh 528 keluarga dengan jumlah penduduk 1.723 jiwa, yang terdiri atas 737 laki- laki dan 986 perempuan. Tingkat pendidikan warga Desa Suka Maju masih rendah, sebagian besar warga hanya mengenyam pendidikan sampai tingkat sekolah dasar (SD). Meskipun ada beberapa orang yang sudah menempuh pendidikan sampai tingkat SMA dan perguruan tinggi, namun jumlahnya masih sangat sedikit. Sebagian besar dari warga yang memiliki pendidikan lebih baik tersebut, juga enggan untuk tinggal di desa. Lulusan SMA/sederajat dan perguruan tinggi tersebut lebih suka bekerja di kota. Dari 1.723 jiwa, jumlah lulusan perguruan tinggi hanya 40 orang dan lulusan SMA 25 orang (Tabel 1).

Tabel 1.Penduduk berdasarkan pendidikan

\begin{tabular}{ll}
\hline Tingkat pendidikan & Jumlah (Jiwa) \\
\hline Tamat Perguruan Tinggi & 40 \\
Tamat SMA & 25 \\
Tamat SMP & 115 \\
Tamat SD & 173 \\
Belum Sekolah & 170 \\
Jumlah & 523 \\
\hline
\end{tabular}

Sumber: Monografi Desa Air Nipis (2017)

Kondisi lingkungan alam dan tingkat pendidikan sangat mempengaruhi pilihan masyarakat dalam memenuhi kebutuhan hidupnya. Dari 528 keluarga, hampir $80 \%$ di antaranya bermata pencaharian sebagai petani atau buruh tani. Hanya sebagian kecil warga yang bekerja di sektor lain, baik bidang jasa, swasta, maupun pegawai negeri sipil. Anak-anak desa banyak yang merantau keluar kota untuk mendapatkan pekerjaan mulai dari pedagang, jasa transportasi, buruh bangunan, pekerja pabrik, menjadi sales/pekerjaan lainnya. Sebagian kecil warga yang menetap ada yang memilih pekerjaan lain seperti pedagang, membuka usaha, atau buruh serabutan. Usaha dagang yang ditekuni berupa jual beli hasil bumi atau membuka warung kelontong untuk pemenuhan kebutuhan hidup warga seharihari (Tabel 2). 
Tabel 2. Penduduk berdasarkan mata pencaharian

\begin{tabular}{lll}
\hline No & Tingkat pendidikan & Jumlah $(\mathrm{KK})$ \\
\hline 1 & Petani & 421 \\
2 & Pedagang & 30 \\
3 & PNS & 19 \\
4 & Buruh & 58 \\
\hline Jumlah & & 528 \\
\hline
\end{tabular}

Sumber: RPJMDes 2017

Tingkat pendidikan yang rendah menyebabkan kemampuan warga untuk memenuhi kebutuhan juga terbatas. Ratarata, warga yang menetap memilih sektor pertanian, dengan pola dan pengetahuan yang terbatas. Mereka menanam komoditas pertanian yang merupakan kebutuhan pokok sehari-hari, seperti padi dan jagung. Tanaman pangan dianggap lebih menguntungkan karena bisa dikonsumsi, dan tanaman lain belum banyak ditanam karena minimnya informasi dan pengetahuan warga.

Sementara itu, lahan yang paling luas berupa hutan rakyat dengan keanekaragaman potensi, belum dimanfaatkan secara maksimal. Tanaman keras yang tumbuh di hutan rakyat tersebut umumnya merupakan tanaman yang tumbuh secara alami, tidak dibudidayakan. Waktu panen yang lama dibandingkan komoditas pangan menyebabkan mereka enggan untuk membudidayakan tanaman keras. Sebagian besar petani di Desa Maju hanya menganggapnya sebagai penghasilan sampingan saja dan dimanfaatkan untuk kepentingan sendiri seperti bahan bangunan dan kayu bakar.

\section{Sejarah pengelolaan sumber daya alam di Desa Suka Maju}

Perkembangan pengelolaan sumber daya alam berbasis masyarakat atau CBNRM di Desa Suka Maju mengalami pasang surut dalam pelaksanaannya. Meskipun demikian, CBNRM dapat berjalan dan berkembang dengan baik karena ada dukungan kebijakan dan peraturan, warga menjadi pelaku utama sejak proses perencanaan, ada kesepakatan bersama yang dijalankan, dan ada keinginan kuat warga untuk selalu berkembang. Faktor-faktor tersebut membuat kepercayaan dan dukungan dari pihak luar semakin kuat sehingga turut mendukung perkembangan CBNRM di Desa Suka Maju.

Ada beberapa sarana yang sangat vital bagi warga, yakni jalan, balai desa, sarana pengairan, baik untuk pertanian maupun pemenuhan kebutuhan hidup sehari-hari, serta masjid sebagai sarana ibadah yang perlu segera dibenahi. Pembangunan atau perbaikan saranasarana vital tersebut membutuhkan modal yang sangat besar. Saat ini penduduk desa sedang merancangkan bagaimana keberlanjutan pembangunan DAS Lubuk Langkap tersebut.

\section{Fungsi/aktivitas pengelolaan sumber daya alam di Desa Suka Maju Perencanaan (Planning)}

Masyarakat Desa Suka Maju sudah melakukan perencanaan partisipatif dalam mengelola potensi sumber daya yang dimiliki. Perencanaan awal pengelolaan sumber daya alam di Desa Suka Maju dihadiri oleh perangkat desa, tokoh masyarakat dan tokoh pemuda. Pada tahap ini perencanaan hanya dilakukan untuk mengelola DAS Lubuk Langkap. Adapun strategi-strategi untuk mencapai tujuan pengelolaan belum ditentukan sehingga kegiatan yang dilakukan masih bersifat spontanitas sesuai arahan kepala desa. Peran kepala desa sangat dominan dalam menentukan langkah-langkah 
pengembangan. "Tahap awal pembentukan panitia pengelolanya memang hanya pemerintahan desa dan perwakilan organisasi, seperti pemuda. Ketika itu kami belum memiliki rencana matang, hanya ingin segera mengembangkan dan mempersiapkan tempat wisata. Dalam pertemuan keputusan bergantung pada kepala desa, seperti pemilihan ketua dan pengurus lain. Terlebih, pengelolaan ini masih tahap awal dan belum tentu berhasil..." (Taswan komunikasi pribadi, 2018). Warga desa berkumpul mengadakan rembug warga dan menyusun Rencana Pembangunan Jangka Menengah Desa (RPJMDes). Rembug warga dilakukan oleh perwakilan unsurunsur masyarakat yang terdiri dari tokoh masyarakat, tokoh agama, tokoh pemuda, perempuan, perangkat desa, dan Dewan Perwakilan Desa.

Model perencanaan tersebut dapat dikategorikan sebagai perencanaan model baru dan memenuhi karakteristik yang diajukan oleh Friedman (1993), yaitu bersifat normatif, inovatif, bersifat politik, transaktif, dan berdasar pada pembelajaran sosial. Perencananya adalah masyarakat desa sendiri dan mereka memegang teguh norma-norma dan nilai ideal yang paling sesuai dengan karakteristik mereka. Dengan demikian Perencanaan yang dilakukan memberikan solusi kreatif dan fleksibel atas permasalahan yang sudah dialami selama berpuluh-puluh tahun. Kepemimpinan yang kuat juga mendukung keberanian untuk merencanakan tindakan baru yang dianggap mampu memberikan solusi terbaik dan bersedia untuk belajar dari kesalahan.

\section{Pengorganisasian (Organizing)}

Pengorganisasian dalam

pengelolaan sumber daya alam di Desa Suka Maju dilakukan sesuai kebutuhan pada awal perencanaan dan secara fleksibel berubah sesuai perkembangan kebutuhan. Kepala desa memegang peranan penting dalam pengorganisasian tersebut. Kepala desa benar-benar memegang peran kebijakan umum, fungsi kontrol, dan melakukan pertanggungjawaban kerja tim yang dibentuk, langsung pada lembaga-lembaga di desa dan warga. Selain itu, kemampuan pemimpin untuk merangkul berbagai pihak, seperti pemimpin terdahulu, tokoh lain di desa yang memiliki pengaruh luas, dan mau menerima pendapat dari pihak luar yang memiliki keahlian khusus dan lebih, membuat arah kepemimpinan yang terbentuk semakin kuat.

Organisasi pengelola yang oleh warga sering disebut sebagai panitia tersebut pemilihan personelnya tidak melalui pemilihan secara demokratis, namun ditunjuk oleh kepala desa yang bertindak sebagai penasehat. Adapun anggotanya terdiri dari perangkat desa dan beberapa tokoh pemuda. Alasan penunjukan tersebut adalah karena pengembangan wisata baru dirintis dan belum menunjukkan hasilnya sehingga dipilih perangkat desa yang bersedia bekerja tanpa dibayar, bahkan sebaliknya harus mengeluarkan dana untuk mendukung pengembangan wisata.

Sumber daya manusia yang dimiliki desa sedapat mungkin ditempatkan pada posisi yang sesuai dengan kapasitas masing-masing sehingga dapat bekerja optimal untuk mencapai tujuan bersama. Demikian pula dengan sarana, prasarana, peralatan, dan modal yang diperoleh dimanfaatkan sedemikian rupa sesuai kesepakatan bersama untuk mengembangkan desa.

\section{Pelaksanaan (Actuating)}

Pengelolaan sumber daya alam berbasis masyarakat melalui desa wisata dilaksanakan bersama-sama oleh semua warga Desa Suka Maju. Pelaksanaannya tidak dapat dilepaskan dari partisipasi aktif masyarakat, pembukaan objek wisata ini berjalan begitu saja. Sarana dan prasarana yang ada di sana masih sangat sederhana, hanya asal tersedia tanpa mempertimbangkan segi estetika. Hal itu terjadi karena sarana dan prasarana 
dikerjakan secara gotong royong, tanpa tenaga ahli bidang wisata. Meski demikian, ada nilai sangat positif dari gotong royong tersebut. Warga yang selalu terlibat aktif menaruh harapan besar bahwa kawasan wisata tersebut dapat berkembang dan merasa memilikinya.

Harapannya setelah wisata ini berkembang dengan baik dan maju diharapkan untuk pendapatan desa yang dapat dimanfaatkan untuk pembangunan sarana dan prasarana desa sehingga dapat dinikmati oleh seluruh warga desa. Pengelolaan sumber daya alam di Desa Suka Maju tidak hanya memberikan manfaat ekonomi, namun juga memberikan manfaat bagi perbaikan lingkungan.

\section{Pengendalian (Controlling)}

Mekanisme pengendalian dalam pengelolaan sumber daya alam di Desa Suka Maju bersifat intern dan melibatkan seluruh warga secara bertahap. Setiap bulan pengurus desa mengadakan rapat evaluasi. Dalam rapat tersebut dilakukan evaluasi

\section{Peran pihak luar dalam CBNRM di Desa Suka Maju}

Keberhasilan sebuah program, terutama di desa memang bergantung pada keinginan kuat dan tekad masyarakat yang mendiami kawasan tersebut. Meski demikian, peranan pihak luar juga tak kalah penting dalam ikut mendukung keberhasilanya. Demikian juga CBNRM di Desa Suka Maju tidak terlepas dari peran pihak luar sebagai agen perubahan (external change agent). Pihak luar tersebut perperan sebagai fasilitator yang membantu mendefinisikan masalah, memberikan saran-saran independen, ide-ide baru, keahlian teknis, memberikan pelatihan dan bantuan teknis, memandu pemecahan masalah dan pengambilan keputusan, serta membantu mengembangkan rencana pengelolaan (Pomeroy, 2001).

\section{Media massa}

Berjalannya CBNRM di Desa Suka Maju dengan pendekatan wisata, tentu tak lepas dari peran media massa. Sebab, penghasilan utama dengan pendekatan ini bergantung pada jumlah kunjungan wisatawan. Faktor ini sangat dipengaruhi oleh dikenal atau tidaknya objek tersebut oleh khalayak luas.

Isu-isu yang dipoles, terutama kemampuan desa untuk memberdayakan diri dan lingkungannya, mampu menarik minat wisatawan untuk berkunjung. Tidak hanya wisatawan yang ingin menkmati atraksi alam, tetapi juga yang ingin mengetahui model pengelolaan yang dilakukan desa, baik lewat studi banding maupun penelitian.

Selain sebagai sarana promosi, posisi pemberitaan media juga menjadi sarana advokasi bagi Desa Suka Maju untuk mendapatkan dukungan dari pihakpihak lain. Terlebih, media massa menjadi salah satu sarana yang kuat untuk memengaruhi seseorang untuk melakukan sesuatu. Hubungan harmonis dengan media massa tersebut menjadi salah satu kunci keberhasilan CBNRM.

\section{Aspek-aspek community based dalam pengelolaan sumber daya alam di Desa Suka Maju keadilan (equity)}

Pengelolaan sumber daya alam berbasis masyarakat melalui desa wisata di Desa Suka Maju memberikan manfaat sosial ekonomi yang lebih adil bagi masyarakat desa. Manfaat ekonomi yang diperoleh dari kegiatan pengelolaan baik secara langsung maupun tidak langsung dinikmati oleh masyarakat desa. Kegiatan pengelolaan tersebut akan membuka lapangan pekerjaan maupun tambahan penghasilan untuk mendukung kehidupan masyarakat.

\section{Pemberdayaan (Empowerment) Resolusi konflik (Conflict resolution)}

Sampai saat ini konflik yang disebabkan karena adanya DAS Lubuk 
Langkap ini belum ada dan masyarakat setempat tetap optimis dan senantiasa bekerjasama satu dengan yang lain untuk mendukung agat tempat ini bisa jadi tempat wisata.

\section{Pengetahuan dan kesadaran (Knowledge and awareness)}

CBNRM membuka peluangpeluang ekonomi baru yang tidak merusak lingkungan, sebaliknya mendukung pelestarian lingkungan. Kearifan lokal yang sudah ada dipadukan dengan pengetahuan ekologi dan manajemen modern untuk mengelola potensi sumber daya alam yang dimiliki.

Melalui CBNRM, mereka menyadari bahwa peningkatan kesejahteraan tidak harus mengorbankan lingkungan. Sebaliknya, masyarakat memperoleh manfaat ekonomi dengan melestarikan lingkungan dan sumber daya alam yang dimiliki. Mereka memadukan kearifan lokal yang sudah diwariskan turun-temurun dengan pengetahuan modern yang diperoleh melalui interaksi dengan pihak lain maupun belajar dari praktek pengelolaan yang dijalankan. Masyarakat desa juga menyadari bahwa keberlanjutan lingkungan desanya terkait erat dengan desa-desa tetangganya dalam satu ekosistem sehingga mereka juga berusaha membangun kerja sama untuk melestarikan lingkungan.

\section{Perlindungan keanekaragaman hayati (Biodiversity protection)}

Perlindungan keanekaragaman hayati menjadi salah satu capaian CBNRM di Desa Suka Maju. Pemanfaatan sumber daya alam sebagai tujuan wisata mendorong masyarakat untuk mengelola lingkungan dan melindungi keanekaragaman hayati beserta habitatnya. Beberapa kegiatan yang dilakukan adalah penghentian tambang batu, pelarangan mengambil ikan dengan racun dan listrik, penghijauan.

\section{Pemanfaatan (Sustainable utilization) \\ berkelanjutan}

Desa Suka Maju belum melakukan kerjasama dengan desa-desa lain untuk mengelola supaya dalam kawasan DAS Lubuk Langkap dapat lebih berkembang lagi. CBNRM dengan pendekatan desa wisata di Desa Suka Maju akan memberikan manfaat ekonomi yang cukup besar bagi masyarakat desa. Selain memberikan lapangan pekerjaan bagi masyarakat juga berkontribusi terhadap pembangunan desa. Keberlanjutan pemanfaatan sumber daya alam tersebut terkait erat dengan perlindungan keanekaragaman hayati (biodiversity protection).

\section{Model implementasi CBNRM dalam Konservasi DAS}

CBNRM berkembang sejak tahun 1980-an dan sangat populer pada dekade berikutnya karena menjadi fokus hampir semua lembaga donor internasional. Meskipun demikian, CBNRM mendapat banyak kritikan dan sebagian besar dianggap gagal (Keller et al. 2000; Blaikie 2006). Pada umumnya, CBNRM tidak dapat memberikan manfaat yang diharapkan bagi masyarakat, yakni pemberdayaan masyarakat, kesejahteraan, dan kelangsungan lingkungan agar dapat menjadi modal pembangunan berkelanjutan.

\section{Kondisi Sosial}

Masyarakat merupakan salah satu unsur penting dalam pengembangan wisata. Pada kasus ini, masyarakat Suka Maju merupakan subjek dari wisata yang berperan dalam mengelola hal tersebut. Hal ini memberikan mobilitas baru bagi masyarakat, sehingga hadirnya ekowisata dapat mempengaruhi proses sosial yang ada di Suka Maju.

\section{Kondisi Ekonomi}

Pengelolaan DAS belum terlihat jelas dampak yang diberikan tetapi telah membuka kesempatan kerja baru kepada 
masyarakat desa. Adanya kesempatan kerja baru dapat menambah penghasilan keluarga. Ekowisata mendatangkan wisatawan yang berkunjung ke kampung ini untuk menikmati keindahan alam sehingga masyarakat dapat menangkap peluang kerja karena hadirnya ekowisata. Kesempatan kerja yang ada baru hanya tukang parker, tukang keamanan dan penjual makanan ringan. Jika dikembangkan lebih baik lagi maka akan membuat lapangan-lapangan pekerjaan baru lagi buat masyarakat desa

\section{Kondisi Budaya}

Perubahan kebudayaan adalah perubahan yang terjadi dikarenakan adanya ketidaksesuaian terhadap unsurunsur budaya. Perubahan kebudayaan biasanya terjadi karena adanya ketidakserasian terhadap fungsi yang ada pada kehidupan. Seiring dengan berkembangnya zaman maka perubahan kebudayaan akan terus terjadi, hal ini dikarenakan perubahan kebudayaan terjadi untuk memenuhi kebutuhan masyarakat. Dengan adanya pengelolaan DAS ini tidak merubah kondisi budaya yang ada selama ini di Desa Suka Maju.

\section{KESIMPULAN}

Kesimpulan yang diperoleh dari hasil penelitian yang telah dilakukan adalah sebagai berikut:

1. Masyarakat Desa Suka Maju telah memiliki pengetahuan dan kesadaran akan ekologi. Dengan adanya sumberdaya DAS ini masyarakat berkeinginan untuk mendapat hasil yang lebih baik untuk meningkatkan kesejahteraan serta tetap memperhatikan dan meningkatkan daya dukung lingkungan.

2. Pada saat ini Desa Suka Maju sedang melakukan fungsi-fungsi/aktifitas pengelolaan sumber daya alam yang meliputi perencanaan (planning) yang dilakukan dengan membangun visi desa, mengidentifikasi dan memetakan potensi desa, mengidentifikasi masalah yang terjadi pada proses pengembangan, pengorganisasian (organizing) yang dipegang langsung oleh Kepala Desa dan di bantu oleh pemuda-pemuda desa, pelaksanaan (actuating) dengan partisipasi aktif dari masyarakat, dan pengendalian (controlling) dilakukan oleh Kepala Desa. Hal ini menandakan bahwa aktivitas pengelolaan sumber daya alam sudah berjalan dengan baik serta masyarakat mampu mengelola sumber daya alam secara partisipatif dan mandiri.

\section{DAFTAR PUSTAKA}

Friedmann J. 1993. Toward a Non Euclidian Mode of Planning. J Amer Plan Assoc 59 (4): 482-485.

Keller SR, Mehta JN, Ebbin SA, Lichtenfeld LL. 2000. Community Natural Resources Management: Promise, Rhetoric, and Reality. Soc Natr Resour 13: 705-715.

Miles MB, Huberman AM. 1992. Analisis Data Kualitatif. Penerbit Universitas Indonesia, Jakarta.

Munasinghe M. 1993. Environmental Economics and Sustainable Development. The World Bank, Washington DC.

Nugroho SP. 2003. Pergeseran kebijakan dan paradigma baru dalam pengelolaan Daerah Aliran Sungai di Indonesia. Jurnal Teknologi Lingkungan 4 (3): 136-142.

Pomeroy, R. 1995. Two to Tango : The Role of Government in Fisheries Co -Management. Marine Policy $21(5): 465-480$.

Sanders D. 1992. Soil Conservation Asia: An Interpretation Perspective. Austri J Soil Water Conser 5 (3): 45-60.

Soemarwoto O. 1989. Ekologi Lingkungan Hidup dan Pembangunan. Djambatan. Jakarta. 
Tripathi PC, Reddy PN. 2008. Principles of Management. 4 ed. Tata McGraw-Hill Publ Co Ltd, New Delhi.

Uphoff, NT. 1998. Feasibility and Application Of Rural Development Participation. A State Of The Art Paper. Ithaca/Cornell University Press.

Wulandari C. 2007. Penguatan Forum DAS sebagai Sarana Pengelolaan DAS secara Terpadu dan
Multipihak. Prosiding Lokakarya Sistem Informasi Pengelolaan DAS: Inisitif Pengembangan Infrastruktur Data. IPB dan CIFOR. Bogor.

Zoebisch M, Cho KM, Hein S, Mowla R. (eds.) 2005. Integrated Watershed Management (Studi and Experiences from Asia). Asian Institute of Technology, Pathumthani. Thailand. 